\title{
SOCIAL CAPITALIZATION OF THE USERS OF FACEBOOK
}

\author{
Dr. KUSHAM LATA ${ }^{\mathbf{1}} \&$ N. SUSHIL K. SIGH ${ }^{2}$ \\ ${ }^{l}$ Assistant Professor, Guru Jambheshwar University of Science\& Technology, Hisar, Haryana, India \\ ${ }^{2}$ Professor, Guru Jambheshwar University of Science \& Technology, Hisar, Haryana, India
}

\begin{abstract}
New media emergence created a new theoretical framework to the sociological concepts. The new world of information created a space to understand the basic concepts with different prospects. Digitalization of content switched the mass media theories to the online environment and this shift opened up the way to encounter the existing theories. This study is constructed on the conceptual framework of 'Social Capital', which was recently studied in an offline context. Social networks crafted 'Social Capitalization' within the online users after the advent of Facebook, Twitter etc. and tremendous opportunities to explore social relationship building.

KEYWORDS: Social Capital, Social Media, Social Exchange, Facebook \& Social Networking Sites
\end{abstract}

Received: Mar 28, 2019; Accepted: Apr 19, 2019; Published: Jun 14, 2019; Paper Id.: IJCMSAUG20192

\section{INTRODUCTION}

\section{SOCIAL CAPITAL: A CONCEPTUAL FRAMEWORK}

The concept of 'social capital' emerged from the sociological background that simply means "the investment in the social relations with expected returns". This notion has been also studied throughout the years for social relations between the political parties. The concept developed in the social sciences, but now has emerged in new media studies also. 'Social capital' a word that first stretch our mind toward 'Capital' i.e cash or property. Capital means the wealth of a person. But when we talk about Social Capital, it means 'wealth of social relationship' or the 'tangible substance' that is count in our daily life to develop our living and growth at the same time.

Development of the interactive media changes the social structure of the society and relationship between the individual. International and intra-national relation are effecting by the use of new media. This new tech-savy generation is connecting with their peers by different mass media tool. The connection through these channels makes a difference in the structure of social relationship. Now the other kind of social capital is building where media play a great role specifically 'Social media'. But firstly we should understand- what is social capital ? Social capital- In Coleman's view in relatively 'close network participation' that will interact in more than one arena, which helps to create the condition for generating social capital. (Whiteley, 1999). There are more argue to be discussed on the theme.

\section{Definition of Social Capital}

\section{According to Bourdieu Definition}

"Social capital is sum of the resources actual and virtual that accrue to an individuals or a group by virtue of possessing a durable network of more or less institutionalized relationship to mutual acquaintance and 
recognition” (Bourdieu, 1992).

\section{Putnam (1993) Defined it as}

"features of social organization, such as trust, norms and network, that can improve the efficiency of the society by facilitating co-ordinated action"(Whiteley,2000).

\section{Krishan (2000) Explained the Term as}

"The term social capital refers either to the capacity of an individual to obtain valued material or symbolic goods by virtue of his or her social relationship and group membership or to the capacity of a plurality of person to enjoy the benefit of collective action by virtue of their own participation, trust in institution, or commitment to established ways doing things" (Ritzer, 2005.)

The basic idea of social capital is that a person's family, friends and associates constitute an important asset who makes a social unit. Connection with our neighbor and other people related to us satisfy our social need and these social relationships improve the condition of the whole community. Social capital is built around trust, norms and obligations. Trust on our fellow mates. "In social structure information flow is governed by users (prod-user) and sustains within trusted network, depends on collective action through the help of social norms to establish interaction for the betterment of individual."

Glenn Loury (1977)describe social capital as- social context in which people achieve something through their social network. People are strongly influenced by the other peer group to grow up in the society. Loury also talked about the social division which is the part of society and also have an impact on it. Financial power of the individual divided them in different class i.e. upper class, middle class and lower class. This division affects the relationship of the people. Inequality between the people encourages them to be equal and achieve some power. In this situation social networks and vulnerable associations help to grow up. Networks play a vital role in the society and without social connection an individual never gain economic capital. Social capital and economic capital are interlinked with each other (Bourdieu, 1986).

Pierre Bourdieu was the first to conceptualize social capital in sociological manner. His notion is also related with the Loury's view. This definition is itself in similar to other definition is, such as we will see in Coleman's concept of the social capital where he also called it a voluntary associations of the people. They benefits through their mutual relationships. Bourdieu defines the social capital as the cold realities of social inequality. He identifies three dimensions of capital- economic, cultural, and social (Bourdieu, 1986). These forms of capital are interlinked with each other. Economic and cultural capital could not be possible without social capital, which is unformed or less tangible.

Bourdieu emphasis on the actual or potential ideas or resources between the relationships. He also emphasis on the power function of the people i.e. social relation that increase the ability of individual to advance his interest. Social capital becomes a resource in the cultural and economic development.

Social capital generates human capital through social support (Coleman, 1988). Coleman's view of the social capital in social context is related with the Loury's view of social structure but he more talked about the social norms, rules, and obligation followed by the society. According to the social structure there could be different entities in social capital. We cannot say that only in a particular situation social capital built. It could be originate in any condition any 
place, any situation and any social structure, where one believe on the others. Any group or community in the society may be a social structure where social capital can take place. Every social field has a profile of its own and every social structure have some obligation, expectation and trust in their relationships. Coleman also defines the flow of information between the social networks. People acquire information through their social connection and there is always some potential in social relation for information. This information exchange between the networks constitutes a powerful form of social capital.

Another area where social relation exist is 'effective norms' found in the closure network. Social norms also arise the positive effect within the external condition. Other researchers also follow this concept and one of the earlier to define this concept in broad and communication perspective is Robert D. Putnam (2000) who defined social capital in two forms-

(1) Relational social capital (2) Institutional social capital. Relational social capital refers to obtain valued material from the social relationships or any group membership. Institutional social capital is the capacity of an active participation in social activities by the group of the people or individual. Social participation and trust on any institutions can help a person to grow up.

Putnam also attempted an expansion of meaning of norms, trust, and obligation and spread this notion more widely. He talked about the "generalized trust". In the modern world we need to develop trust among the relationship to live the sphere based on familiarities. Voluntary associations are dealt with sole source of trust. He generalized the view that factor behind the economic and governmental effectiveness is the active participation of the civic community and trust is more a positive value with the respect to development. Coleman also emphasis the notion that more the social capital use, more the trust grow (Coleman, 1988). The form of social capital is self-reinforcing by nature. Various circle in society expressed as distrust, breaking of the norms, avoiding one's duties, isolation.

Social norms are belief about what is acceptable in social context. Social norms are the rules that a group uses for appropriate and inappropriate values, beliefs, attitude and behavior. Norms are cultural phenomenon that prescribe and proscribe behavior in specific circumstances. Without norms it is hard to imagine how interaction and exchange between strangers take place at all. The social norms is refers to what one should do and don't do in a given situation (Dubois, 2003).

Finally social capital thus has component like- it is first a resource that is connected with groups of people and social networks. Membership of groups and involvement in social network develops and improve the social position of the people. Political parties, organizations, trade union, educational groups etc. are the example of traditional social capital. But we will study the social capital in modern context where internet has change and affect the social life of the individual very much with more interesting and participatory features. Social media has opened the way to rethink about the social relationship building and the way in which social connection will be improved. So in modern context social capital could be defined by the researcher as- "active participation, virtual connectedness of mutual relationships and information acquisition between diverse groups".

\section{Facebook use and Social Capital}

As far as Facebook is concerned social capital grow among individual. In the last few years in India social media helps to mobilize the masses. Research studies conducted on the use of social media indicated that human relation are building and bridging through the use of social networking sites. Facebook mobilize the different groups, races and religion 
. The use of online media change the overall attitude of the surfing internet. In social context facebook create a wide space to interact people at large scale on social interest, political and economic affairs. Facebook is a general social networking site. It is famous primary for the self-disclosure by the users. Self-Disclosure is the revealing of the personally relevant experience, thoughts, and feelings to other (Tian, 2011). Self-disclosure is essential to the development and maintenance of close relationships. People who are able to disclose their true self are more likely to form relationship with others. According to Derlega and Chaikin (1977), individual do not engage in self disclosure until trust has been established between them because of the potential leak of the intimate information to mutual acquaintances and the possibility of being ridiculed or rejected. That why facebook has trusted contact having billions of users online and helpful to create social capital through more diverse social resources.

\section{Negative Impact of Facebook}

There are always advantage and disadvantage of a medium by its functions. Human behavior is not static that's why every network has it limitation to effect the mind of the people. Some of the users may take it for positive action and on the other it may negatively harm the users. It depends on particular personality how they use the medium. Collective action could generate by the use of social networking site and also could target somebody for destruction.

According to a research study conducted in Missouri University, Psychologist concluded that a person's facebook profile may reveal the mental illness that might not be emerged in psychiatrist session. Social media activity that person chose to conceal exposed information about their psychological state (TOI, 2013).

Facebook has the positive as well as negative impact on the society. On the one hand it connect the people for betterment and valuable relation building, on the other hand it brings difficulties for most of the people. Fake profile and hacking of account disturb users by posting explicit content. Cases had registered under section -66(A) of IT Act on the comments given by Facebook users on the wall posts or by any other gesture on SNS. The most hiked case on Facebook sharing was registered in Mumbai in 2012, when two girls from Palghar gave an innocuous statement that was posted by Shaheen Dhada on her Facebook account on November 18, 2012 after the death of Bal Thackeray. Another girl was charged for liking the post. The girl simply post -

"Every day thousands of people die. But still the world moves on. Just due to one politician dead, a natural death everyone just goes crazy.. they should know. We are resilient by force not by choice. When was the last time did anyone show some respect or even a 2mins silence for Shaheed Bhagat Singh, Azad, Sukhdev or any of the people because of whom we r free living Indians...respect is earned not given and definitely not forced. Today, Mumbai shuts down due to fear not due to respect!!" (The Economic Times, 2015)

These words had taken the girl in to trouble only because of the facebook. The women were earlier booked for hurting religious sentiments under Section 295A of the Indian Penal Code, along with Section 66A of the Information Technology Act. The question here rises against the freedom of speech and expression on social media and after compressing the issue by people case was discharged. Information Technology Act sec- 66 (A) amended after that to secure the uses of Facebook.

Every day we encounter with lots of cases that affected the people because of the heavy usage of Facebook. A girl from Bangalore hang herself after rejected to chat on facebook by her boyfriend. Who mislead her and present himself as what exactly he was not (TOI, $7^{\text {th }}$ Nov. 2013). Another incident was happed in Delhi where a new born baby sold three 
times in 10 days on Facebook by his grandmother and other persons (The Hindu, 2013). Fake accounts, Pages, content and missing news is floating on the Facebook to catch the user's attention. The site has both kind of content that negotiate the happening around us. It has the ability to bring change through trusted contacts and also can ruin the life of peoples by misinformation. Strong reactions were recorded on many facebook posts and this approach also activated the mind of other passive users.

Finally to conclude- this study is formulate to understand some basic question about Facebook use and its implication to build or bridging of social capital of a human being. The main question arise that how do we engage on facebook and what is reason to use the facebook. This is a deep study on the content of facebook users. Therefore, as a logical extension of above described area, it is necessary to look out major consequences of using the site; social media nowadays play a fundamental role for societal changes and for personal relationship improvement as well. However, many studies have been carried out on this nascent topic and on the modern interconnection between new media and social media, the actual effectiveness of social media usage especially social relations building is important to study. The present topic was chosen for the study as emerging of social media in India too. When Facebook was on its initial stage and people were learning how to use social media, the radical change takes place rapidly because of the highly acceptable technology which is interesting and easy to use. In a short span of time it went popular medium for interaction so the need to study a new medium of communication ruminate. The power of SNS made it a self-propagation tool, information acquisition centre and also an entertainment seeking platform for the vast audience. So the present study explored the working of a social networking site by particular users.

\section{Theoretical Background of the Study}

For every research it is necessary to have a theoretical background for conceptualize the broad objectives. The approach for this research is on the theory of 'Social Capital' that has been followed throughout the years to measure the social relationship building on sociological perspective. Advent of the new media specifically 'social media' reconceptualizes the term. Many Researchers found that social media has increased the social capital of individual (Ellison, Steinfield, \& Lamp, 2006, Valenzuela, Park, and Kee 2009). Especially Facebook provide a platform to people to gather online and helpful in building and bridging social capital through social resources which is available online easily. As Putnam (2000) suggests in his study social capital has three main factors - Social Network, Social Norms and Social Trust. These are basic component to understand the term and for this study these factors identified to examine the online usage of the social networking sites. 
Table 1

\begin{tabular}{|c|c|}
\hline Social Norms & $\begin{array}{l}\text { In the process of socialization human behavior plays a significant role in building } \\
\text { relationship among the individuals in the community or society. This follows certain } \\
\text { norms which characteristic and customary in the society. This social behavior can be } \\
\text { called social Norms. James Coleman (1988) define that social norms, obligations and } \\
\text { rules followed by individual in social and cultural context subjects to fulfill their goals. } \\
\text { He also claim that norms reinforced by social support, status, honor and other rewards. } \\
\text { Putnam (1993) described about the main feature of social life as- network, norms and } \\
\text { trust - that enable participant to act together more effectively to pursue shared objective. } \\
\text { Dubois (2003) defined norms as whatever most members of a given group do or think. }\end{array}$ \\
\hline Social Trust & $\begin{array}{l}\text { Interaction between the close networks in daily life by the same group, class or } \\
\text { community generates reliability on each other. In social context this reliability on each } \\
\text { other can be called social trust. Trust is an essential ingredient to formulate the human } \\
\text { relationship. Trust on other is more important to build a healthy relationship. } \\
\text { Durkheimian defined trust as 'Thick Trust' which is generated through the tight and } \\
\text { intensive networks between the people. Trust formed in total institution such as family, } \\
\text { neighbor and close relationship in same group. Tocqueville describe that in modern } \\
\text { society does not generate the 'thick' trust but 'thin' trust. It means that social contact } \\
\text { between loose ties and voluntary associations also generates trust. Putnam (1993) also } \\
\text { said that 'people who join a group who trust and that 'the causation flows mainly from } \\
\text { joining too trusting' (Newton, 1999). Uslaner (2002) consider social trust as a stable trait } \\
\text { determined by socialization process. Trust is built upon imperfect knowledge. } \\
\text { (Valenzuela, park, kee,2009). According to this research the detailed information of the } \\
\text { social network user about their contact, basic information, interest, likes etc. develop a } \\
\text { norm of trust. Trust-described by the researcher as the expectation arises within the } \\
\text { society that based on corporative behaviour and commonly shared social norms. In } \\
\text { online environment no actual transaction takes place so it become difficult to measure } \\
\text { the content but the trust can be generated through social relations. (Warren et al. 2014) }\end{array}$ \\
\hline Social & $\begin{array}{l}\text { In society there are some nodes to connect every individual through there interpersonal } \\
\text { connections. These nodes are called social network. The concept of social network has } \\
\text { emerged as a key technique in the modern sociology. It has also gained a significant } \\
\text { following in the anthropology, biology, communication studies, and has become a } \\
\text { popular topic of study. George Simmel was the first who used the term 'social network' } \\
\text { in his work. He called the social network as the number and the type of people with } \\
\text { whom we associate, and connection among and between the people (Allan, 2007). Social } \\
\text { network have also been used to examine how organizations interact with each other, } \\
\text { characterizing the many informal connections that link executive together, as well as } \\
\text { association and connections between individual employees at different organizations. } \\
\text { For example, power within organization often comes more from the degree to which an } \\
\text { individual within a network is at the center of the many relationships than actual job } \\
\text { title. (Mathur, 2011). So this research is decorated around these three factors. }\end{array}$ \\
\hline Social exchange & $\begin{array}{l}\text { Social exchange is a concept of transaction of resources through interpersonal } \\
\text { relationships. In social context relationship can be seen as interactions in which the } \\
\text { action of one actor during process takes into account the action of the other actors. } \\
\text { Social exchange is more than social interaction because this has an added element of } \\
\text { resource transaction. George Homans (1958) define it as 'interaction between people is } \\
\text { an exchange of goods, material and non material'. The interest of the two actors on } \\
\text { continuing the interaction and the main focus of the social behavior is on gain (value). } \\
\text { The relationship between the individual is most important here. With the help of power } \\
\text { distribution one can get the maximum gain. }\end{array}$ \\
\hline
\end{tabular}

The social exchange of massages has become so affordable for the individual in new media environment that everyone has the facility to grow up in society by maximum use of its resources. Another factor that is creating social capital is the quest for social recognition. Social media has given that platform to the users to establish identity online with the help of offline foundations. After go through the literature these main factor were found to conceptualize the social capital in term of facebook usage. 


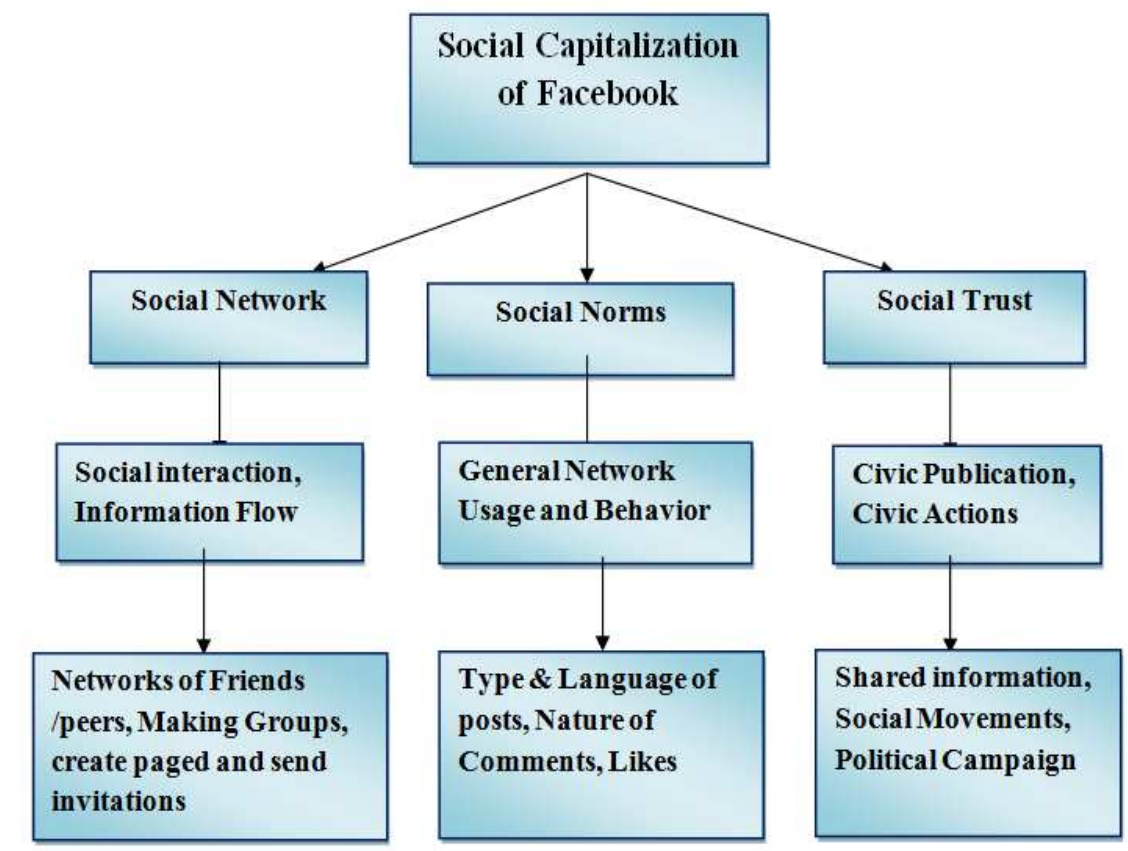

(This model is drawn after empirically reviewing the literature on the concept 'Social Capital)

Figure 1: Graphic Representation of Social Capitalization of Facebook

\section{METHODOLOGY}

The Broad objective is to study the participation in social and popular issues from time to time and to study general social network behaviour of facebook users.

\section{Content Analysis}

To study the massage of the media channels content analysis is the best method. For this research content analysis adopted as the method to empirically investigate the content of social media. This is included the text, images, video and audio format of the content of social networking site 'Facebook'. The basic quality of content analysis is quantitative analysis of the material found in any form but for this study both quantitative and qualitative techniques is adopted to simplify the phenomenon. Sample size for the research was 300 hundred users of facebook collected through the original profile of the researcher.

\section{Systematic Random Sampling}

Systematic random sampling is a practical way to select every $i$ th item from the list. So for this study every $4^{\text {th }}$ day from the list has been selected because six months data was not convenient for data analysis. Each day lots of posts were shared by the users on facebook and the previous posts also appeared again in the newsfeed whenever a mutual friend likes or comment on that. Repetition of content emphasizes the researcher to set a limit. Content has been formulized in Nominal scale and all parameters has construct in numbers to calculate the percentage. Maximum parameter has been developed by the researcher and some of the parameters have taken from the other studies.

\section{Data Analysis}

The following table represents the relation between profile photo of the users adopted to display on their facebook page and the gender mentioned in the profile. 
Table 2: Categories of the Profile Photos and Gender Mentioned by the users of Facebook

\begin{tabular}{|l|l|c|c|c|}
\hline \multicolumn{5}{|c|}{ Profile Photos and Gender Mentioned by the users of Facebook } \\
\hline \multicolumn{2}{|c|}{ Profile Photo of the user } & \multicolumn{2}{c|}{ Gender Mentioned } & \\
\hline & & Male & Female & Total \\
\hline Original & Count & 183 & 74 & 257 \\
\hline & $\%$ of Total & $61.0 \%$ & $24.7 \%$ & $85.7 \%$ \\
\hline Public figure & Count & 3 & 3 & 6 \\
\hline & $\%$ of Total & $1.0 \%$ & $1.0 \%$ & $2.0 \%$ \\
\hline Emoticons & Count & 0 & 2 & 2 \\
\hline Nature & $\%$ of Total & $0.0 \%$ & $0.7 \%$ & $0.7 \%$ \\
\hline & Count & 1 & 4 & 5 \\
\hline Fictitious characters & \% of Total & $0.3 \%$ & $1.3 \%$ & $1.7 \%$ \\
\hline & Count & 0 & 5 & 5 \\
\hline Formatted & $\%$ of Total & $0.0 \%$ & $1.7 \%$ & $1.7 \%$ \\
\hline & Count & 3 & 11 & 14 \\
\hline Anonymous & $\%$ of Total & $1.0 \%$ & $3.7 \%$ & $4.7 \%$ \\
\hline & Count & 6 & 1 & 7 \\
\hline None & $\%$ of Total & $2.0 \%$ & $0.3 \%$ & $2.3 \%$ \\
\hline & Count & 1 & 3 & 4 \\
\hline Total & $\%$ of Total & $0.3 \%$ & $1.0 \%$ & $1.3 \%$ \\
\hline & Count & 197 & 103 & 300 \\
\hline
\end{tabular}

(Source: primary data)

While undergoing through the data it is found that majority of the user have 'original picture' on their profile that is of the total of male and females ( 85.7 percent) and males used original profile pictures more, (61.0 percent) compared to females (24.7 percent). Other than original we have the function to choice any photo recorded in our device. 'Formatted photos' were also uploading by the user in form of formatted quotations and other picture with written words (4.7 percent). Females were found much used the 'formatted photos' (3.7 percent) then the males (1.0 percent).

Conclusions- Presenting himself/ herself on the facebook decides how a user wants to connect on social networking site. If he/she uploads their 'original photo' they wish to connect with original identity. If they are uploading other type of picture they might be conscious of using the site. Males are leading in the category of depicting original display picture than females. They are more likely to hide their identity and used 'formatted photos'. 
Table 3: Cross-Tabulation between 'Topic of the Status update' and 'Subject of the Post'

\begin{tabular}{|c|c|c|c|c|c|c|c|c|c|}
\hline \multicolumn{10}{|c|}{ Topic of the Status update and Subject of the Post } \\
\hline $\begin{array}{l}\text { Topic of the } \\
\text { Status update }\end{array}$ & None & $\begin{array}{c}\text { News } \\
\text { Element }\end{array}$ & Entertainment & $\begin{array}{c}\text { Personal } \\
\text { Comments }\end{array}$ & $\begin{array}{l}\text { Unfiltered } \\
\text { News }\end{array}$ & $\begin{array}{c}\text { Massage/ } \\
\text { Appeal }\end{array}$ & Promotional & Other & Total \\
\hline \multirow[t]{2}{*}{$\begin{array}{l}\text { Self- } \\
\text { presentation }\end{array}$} & 0 & 93 & 235 & 137 & 0 & 10 & 0 & 0 & 475 \\
\hline & $0.0 \%$ & $4.5 \%$ & $11.5 \%$ & $6.7 \%$ & $0.0 \%$ & $0.4 \%$ & $0.0 \%$ & $0.0 \%$ & $23.2 \%$ \\
\hline \multirow[t]{2}{*}{ Socialissue } & 0 & 110 & 35 & 76 & 100 & 33 & 0 & 0 & 354 \\
\hline & $0.0 \%$ & $5.3 \%$ & $1.7 \%$ & $3.7 \%$ & $4.9 \%$ & $1.6 \%$ & $0.0 \%$ & $0.0 \%$ & $17.3 \%$ \\
\hline \multirow[t]{2}{*}{ Political issue } & 0 & 28 & 22 & 21 & 15 & 16 & 5 & 0 & 107 \\
\hline & $0.0 \%$ & $1.3 \%$ & $1.1 \%$ & $1.0 \%$ & $0.7 \%$ & $0.8 \%$ & $0.2 \%$ & $0.0 \%$ & $5.2 \%$ \\
\hline \multirow{2}{*}{ Health issue } & 0 & 35 & 0 & 15 & 10 & 5 & 0 & 0 & 65 \\
\hline & $0.0 \%$ & $1.7 \%$ & $0.0 \%$ & $0.7 \%$ & $0.5 \%$ & $0.2 \%$ & $0.0 \%$ & $0.0 \%$ & $3.2 \%$ \\
\hline \multirow[t]{2}{*}{ Education } & 0 & 67 & 0 & 5 & 14 & 0 & 0 & 0 & 86 \\
\hline & $0.0 \%$ & $3.2 \%$ & $0.0 \%$ & $0.2 \%$ & $0.6 \%$ & $0.0 \%$ & $0.0 \%$ & $0.0 \%$ & $4.2 \%$ \\
\hline \multirow[t]{2}{*}{ Cinema/Songs } & 0 & 4 & 45 & 9 & 0 & 0 & 0 & 0 & 59 \\
\hline & $0.0 \%$ & $0.2 \%$ & $2.1 \%$ & $0.4 \%$ & $0.0 \%$ & $0.0 \%$ & $0.0 \%$ & $0.0 \%$ & $2.9 \%$ \\
\hline \multirow[t]{2}{*}{$\begin{array}{l}\text { Poetic } \\
\text { Expression }\end{array}$} & 0 & 0 & 164 & 28 & 0 & 0 & 0 & 0 & 202 \\
\hline & $0.0 \%$ & $0 . \%$ & $8.0 \%$ & $1.4 \%$ & $0.0 \%$ & $0.0 \%$ & $0.0 \%$ & $0.0 \%$ & $9.9 \%$ \\
\hline \multirow[t]{2}{*}{ Business } & 0 & 7 & 0 & 0 & 0 & 0 & 6 & 0 & 6 \\
\hline & $0.0 \%$ & $0.3 \%$ & $0.0 \%$ & $0.0 \%$ & $0.0 \%$ & $0.0 \%$ & $0.3 \%$ & $0.0 \%$ & $0.3 \%$ \\
\hline \multirow[t]{2}{*}{$\begin{array}{l}\text { Thoughts/quote } \\
\text { s }\end{array}$} & 0 & 0 & 181 & 39 & 0 & 20 & 0 & 0 & 240 \\
\hline & $0.0 \%$ & $0.0 \%$ & $8.9 \%$ & $1.9 \%$ & $0.0 \%$ & $1.0 \%$ & $0.0 \%$ & $0.0 \%$ & $11.7 \%$ \\
\hline \multirow[t]{2}{*}{ Sports } & 0 & 7 & 10 & 7 & 0 & 0 & 0 & 0 & 18 \\
\hline & $0.0 \%$ & $0.2 \%$ & $0.5 \%$ & $0.3 \%$ & $0.0 \%$ & $0.0 \%$ & $0.0 \%$ & $0.0 \%$ & $0.9 \%$ \\
\hline \multirow[t]{2}{*}{ Culture } & 0 & 27 & 61 & 10 & 25 & 29 & 0 & 0 & 161 \\
\hline & $0.0 \%$ & $1.2 \%$ & $3.2 \%$ & $0.4 \%$ & $1.1 \%$ & $1.4 \%$ & $0.0 \%$ & $0.0 \%$ & $7.9 \%$ \\
\hline \multirow[t]{2}{*}{$\begin{array}{l}\text { Natural } \\
\text { disaster }\end{array}$} & 0 & 7 & 1 & 0 & 4 & 1 & 0 & 5 & 18 \\
\hline & $0.0 \%$ & $0.3 \%$ & $0.0 \%$ & $0.0 \%$ & $0.1 \%$ & $0.0 \%$ & $0.0 \%$ & $0.2 \%$ & $0.9 \%$ \\
\hline \multirow[t]{2}{*}{ Humours } & 0 & 5 & 65 & 10 & 0 & 0 & 0 & 0 & 80 \\
\hline & $0.0 \%$ & $0.2 \%$ & $3.2 \%$ & $0.5 \%$ & $0.0 \%$ & $0.0 \%$ & $0.0 \%$ & $0.0 \%$ & $3.9 \%$ \\
\hline \multirow[t]{2}{*}{ Provocative } & 0 & 4 & 2 & 0 & 0 & 10 & 0 & 0 & 16 \\
\hline & $0.0 \%$ & $0.2 \%$ & $0.1 \%$ & $0.0 \%$ & $0.0 \%$ & $0.5 \%$ & $0.0 \%$ & $0.0 \%$ & $0.8 \%$ \\
\hline $\begin{array}{l}\text { Science \& } \\
\text { technology }\end{array}$ & 0 & 10 & 0 & 0 & 6 & 0 & 5 & 0 & 21 \\
\hline
\end{tabular}

In the above table it is evident that mostly facebook is used for 'entertainment' purpose (44.0 percent) and the main content that is use for entertainment most of the time is 'self-presentation' where people publish content as own photographs, comments, personal event, own creations ( 23.2 percent). Cross-tabulation between 'topic of the post' and the 'subject of the post' depicting here that in 'entertainment' category highest number of sharing a issue is self-presentation (11.5 percent). Self-presentation adopted here as - personal information of the user, sharing personal photos or videos, life events. Secondly the social issues were more discussed by the users and large number of posts is found also on social issues (17.3 percent). Subject of the social issues is higher in news element (5.3 percent). In total category of information got the second highest percentage including filtered information (19.1 percent) and unfiltered information (8.8 percent) in total (27.9 percent). Third category is personal comment (17.6 percent) given by the users on the wall through their own observation on a particular phenomenon.

Conclusion - Main findings of the table suggests that usually facebook is used for entertainment purpose through self-presentation, but it is also observed that users seek information by shared content on social issues.

Following table is the Cross-tabulation between the main variable 'topic of the post and the nature of comment given by the other users on a particular post. 
Table 4: Cross-Tabulation between Topic of the Post and Nature of the Comments Posted by the users

\begin{tabular}{|c|c|c|c|c|c|c|c|c|}
\hline \multicolumn{9}{|c|}{ Topic of the Post and Nature of the Comments Posed by the users } \\
\hline \multicolumn{2}{|c|}{ Topic of the Post } & \multicolumn{6}{|c|}{ Nature of Comments } & \multirow[b]{2}{*}{ Total } \\
\hline & None & Formal & $\begin{array}{l}\text { Off the } \\
\text { Topic }\end{array}$ & Opinion & Personal & $\begin{array}{l}\text { Abusive/Hate } \\
\text { Speech }\end{array}$ & Appreciate & \\
\hline \multirow[t]{2}{*}{$\begin{array}{l}\text { Self- } \\
\text { presentation }\end{array}$} & 162 & 210 & 0 & 22 & 59 & 0 & 22 & 475 \\
\hline & $7.9 \%$ & $10.3 \%$ & $0.0 \%$ & $1.1 \%$ & $2.9 \%$ & $0.0 \%$ & $1.0 \%$ & $23.2 \%$ \\
\hline \multirow[t]{2}{*}{ Social issue } & 188 & 69 & 0 & 75 & 10 & 1 & 11 & 354 \\
\hline & $9.2 \%$ & $3.4 \%$ & $0.0 \%$ & $3.7 \%$ & $0.5 \%$ & $0.0 \%$ & $0.4 \%$ & $17.3 \%$ \\
\hline \multirow[t]{2}{*}{ Political } & 64 & 16 & 5 & 14 & 0 & 0 & 8 & 107 \\
\hline & $3.1 \%$ & $0.8 \%$ & $0.2 \%$ & $0.7 \%$ & $0.0 \%$ & $0.0 \%$ & $0.4 \%$ & $5.2 \%$ \\
\hline \multirow[t]{2}{*}{ Health } & 26 & 10 & 0 & 14 & 5 & 0 & 10 & 65 \\
\hline & $1.3 \%$ & $0.5 \%$ & $0.0 \%$ & $0.7 \%$ & $0.2 \%$ & $0.0 \%$ & $0.5 \%$ & $3.2 \%$ \\
\hline \multirow[t]{2}{*}{ Education } & 57 & 25 & 0 & 4 & 0 & 0 & 0 & 86 \\
\hline & $2.8 \%$ & $1.2 \%$ & $0.0 \%$ & $0.2 \%$ & $0.0 \%$ & $0.0 \%$ & $0.0 \%$ & $4.2 \%$ \\
\hline \multirow[t]{2}{*}{ Cinema/ Songs } & 19 & 16 & 4 & 10 & 0 & 0 & 10 & 59 \\
\hline & $0.9 \%$ & $0.8 \%$ & $0.2 \%$ & $0.5 \%$ & $0.0 \%$ & $0.0 \%$ & $0.5 \%$ & $2.9 \%$ \\
\hline \multirow[t]{2}{*}{$\begin{array}{l}\text { Poetic } \\
\text { Expression }\end{array}$} & 88 & 40 & 0 & 29 & 15 & 0 & 30 & 202 \\
\hline & $4.3 \%$ & $2.0 \%$ & $0.0 \%$ & $1.4 \%$ & $0.7 \%$ & $0.0 \%$ & $1.4 \%$ & $9.9 \%$ \\
\hline \multirow[t]{2}{*}{ Thoughts/quotes } & 131 & 70 & 0 & 9 & 5 & 0 & 26 & 240 \\
\hline & $6.4 \%$ & $3.4 \%$ & $0.0 \%$ & $0.4 \%$ & $0.2 \%$ & $0.0 \%$ & $1.2 \%$ & $11.7 \%$ \\
\hline \multirow[t]{2}{*}{ Sports } & 0 & 16 & 1 & 1 & 0 & 0 & 0 & 18 \\
\hline & $0.0 \%$ & $0.8 \%$ & $0.0 \%$ & $0.0 \%$ & $0.0 \%$ & $0.0 \%$ & $0.0 \%$ & $0.9 \%$ \\
\hline \multirow[t]{2}{*}{ Culture } & 74 & 66 & 0 & 5 & 10 & 0 & 6 & 157 \\
\hline & $3.6 \%$ & $3.2 \%$ & $0.0 \%$ & $0.2 \%$ & $0.5 \%$ & $0.0 \%$ & $0.2 \%$ & $7.7 \%$ \\
\hline \multirow[t]{2}{*}{ Crisis } & 9 & 2 & 0 & 2 & 5 & 0 & 0 & 18 \\
\hline & $0.4 \%$ & $0.1 \%$ & $0.0 \%$ & $0.1 \%$ & $0.2 \%$ & $0.0 \%$ & $0.0 \%$ & $0.9 \%$ \\
\hline \multirow[t]{2}{*}{ Humorous } & 40 & 30 & 0 & 0 & 0 & 0 & 10 & 80 \\
\hline & $2.0 \%$ & $1.5 \%$ & $0.0 \%$ & $0.0 \%$ & $0.0 \%$ & $0.0 \%$ & $0.4 \%$ & $3.9 \%$ \\
\hline \multirow[t]{2}{*}{ Provocative } & 1 & 0 & 0 & 0 & 0 & 15 & 0 & 16 \\
\hline & $0.0 \%$ & $0.0 \%$ & $0.0 \%$ & $0.0 \%$ & $0.0 \%$ & $0.7 \%$ & $0.0 \%$ & $0.8 \%$ \\
\hline \multirow[t]{2}{*}{$\begin{array}{l}\text { Science \& } \\
\text { technology }\end{array}$} & 12 & 0 & 0 & 4 & 5 & 0 & 0 & 21 \\
\hline & $0.6 \%$ & $0.0 \%$ & $0.0 \%$ & $0.2 \%$ & $0.2 \%$ & $0.0 \%$ & $0.0 \%$ & $1.0 \%$ \\
\hline \multirow[t]{2}{*}{ Others } & 28 & 18 & 0 & 0 & 0 & 0 & 1 & 47 \\
\hline & $1.3 \%$ & $0.9 \%$ & $0.0 \%$ & $0.0 \%$ & $0.0 \%$ & $0.0 \%$ & $0.0 \%$ & $2.3 \%$ \\
\hline \multirow[t]{2}{*}{ None } & 50 & 32 & 0 & 0 & 4 & 4 & 5 & 95 \\
\hline & $2.4 \%$ & $1.6 \%$ & $0.0 \%$ & $0.0 \%$ & $0.2 \%$ & $0.2 \%$ & $0.2 \%$ & $4.6 \%$ \\
\hline \multirow[t]{2}{*}{ Total } & 949 & 620 & 10 & 189 & 118 & 20 & 123 & 2045 \\
\hline & $46.4 \%$ & $30.3 \%$ & $0.5 \%$ & $9.2 \%$ & $5.8 \%$ & $0.9 \%$ & $6.8 \%$ & $100.0 \%$ \\
\hline
\end{tabular}

(Source : Primary Data, Cross-tabulation by SPSS version 20)

This table identified that most of the comments were on self-presentation (7.9 percent). For example people give comments the photos of close friends, peer groups or the personal he/she exactly knows. It is just an effortless notion to praise someone in formal way. 'Opinions' were more expressed in the category of 'social issues' (3.7 percent) than the 'formal' comment which is the highest in all categories. Posts that were related to 'political issues' also has 'no comment' on most of the post (3.1 percent). 


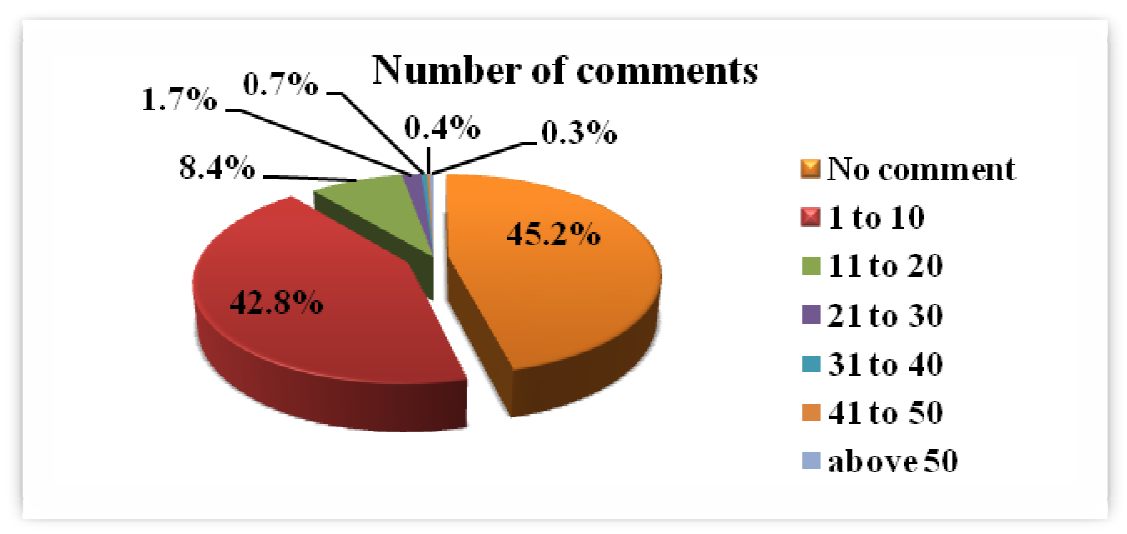

Figure 2

Conclusion- So the findings reveals that usually users feedback is passive to give any comment on a post or very formal comments with limited words that is common for social networking. But on social and political issues people also expressed their opinion and take part in conversation.

\section{CONCLUSIONS}

- The acceptance for the use of profile picture for self-propagation creates a strong relationship with social trust here. It means, online user's first step to link with the social networks found exclusively reliable. The main reason behind the use of profile picture by most of the users is the self-identity formation.

- It may assume here that if maximum content is for entertainment, chances are more to identify it as less innovative or creative way to socialize because most of the content is personal photos or phrases written by others only. Own created material has little appearance. The combination of entertainment along with self-disclosure generates narcissism among the users of Facebook. (Selfies, Place visited, current status, likes and comments)

- In the process of socialization it is important to express own view, but the view should be on the interest for others. The view counted in the study are personal comment on own deeds. So it can be associated with socialization. Formal comments included fairly a notion of appreciation, motivation or some time just obligation to reply with few words. This is a social norm because every time users have to comments on their close friend's post just for sake of obligation. Significantly this finding is associated with social norms and obligation.

\section{REFERENCES}

1. Allan, k. (2007). The Social Network Lens: An Invitation to social and sociological Theory. Chap.4, pp. 120-121. USA: Sage.

2. Appelrouth, S. \& Edles, L.D. (2012). Classical and Contemporary Sociological Theory: Text and Reading. USA: SAGE.

3. Barnes, N., Edwards, S.P. \& Sim, Ch. (2015). A dialogic about using facebook status updates for education research: a Ph.d student's journey, Educational Research and Evaluation, 21:2, Retrieved on 14 april, 2015 fromhttp://dx.doi.org/10.1080/13803611.2015.1024429

4. Bourdieu, Pierre (1986). 'Distinction: A Social Critique of the Judgement of Taste'. Translated by Richard Nice. London: Routledge and Kegan Paul. Citation from <books.google.co.in>

5. Bourdieu, Pierre and Wacquant, Loic,(1992). An Invitation of Reflexive Sociology. Cambrige: U.K. citation from <scholar.google.co.in> 
6. Boyd D. M, Ellison N. B.(2007) Social Networking Sites: Definition, History, and Scholarship.' Journal of Computer Mediated Communication. 13 (1) Special issue by JCMC on social network sites. Retrived on 15th nov. 2012 from $\langle$ www.danah.org/researchBibs/sns.php $>$

7. Brajnik, G., \& Gabrielli, S. (2010). A Review of Online Advertising Effects on the User Experience. International Journal of Human-computer Interaction, 26(10), 971-997. http://www.tandfonline.com/loi/hihc20

8. Brooke, B, Welser, H.T, Hogan, B. \& Titswoth (2011). Socioeconomic Status Updates. Information, Communication \& Society, 14(4), 529-549. Retrieved from 〈http:dx.doi.org/10.1080/1369118X.2011.562221>

9. Burt, S. Ronald (1992). The Network Structure of social capital. Research in Organizational Behaviour, vol. 22, $345-423$.

10. Cecconi A. (2007) Research paper on Social Networking: Research Paper on Social Netwoking. Retrieved on 15 th Nov. 2012 from 〈www.danah.org/researchBibs/sns.php>

11. Clegg Smith, K. M. (2004). Electronic eavesdropping: The ethical involved in conducting a virtual ethnography. In M.D Johns, S., L.S Chen \& G.J. Hall (Eds). Online social research: Method, issues \& ethics (pp. 223-238). New York, NY: Peter Lang.

12. Coleman, James.(1988). 'Social Capital in the Creation of Human Capital'. American Journal of Sociology, 94 (1), $95-120$. Retrieved on January 24, 2013 from http://www.jstor.org.com.

13. Courtois, C., Mechant, P., De Marez, L., and Verleye, G. (2009). Gratifications and Seeding Behavior of Online Adolescents. Journal of Computer-Mediated Communication, vol-15, no-(1), pp.-109-137. Retrieved from http://onlinelibrary.wiley.com/journal/10.1111/(ISSN)1083-6101

14. Dijk, Jan Van (2006). The Network Society: Social Aspects of New media (2nd ed). Chap. 1, (P.9). London: SAGE

15. Dominick, J. (1999). Who do you think you are? Personal home pages and self-presentation on the World Wide Web. Journalism and Mass Communication Quarterly, 76(4), 646-658.

16. Mahjoub, S. J., Sadeghi, A., \& Asghari, F. Survey of Relational Skills Training Effectiveness on Students'self-Expression, Social Acceptance and Academic Achievement (Case Study: Fouman City, Guilan Province, Iran).

17. Dubis, N. (2003). A Socio-cognitive Approach to Social Norms. Pub: Routledge: Newyork. p.1.〈googlebooks.co.in>

18. Dubois, N. (Eds). (2003). A Socio-cognitive Approach to social Norms. Chap.1, p.1.New York: Routledge.

19. Ebersole S. (2000) "Uses and Gratification of Web Among the Students". Journal of Computer Mediated Communication. 6 (1), Sep. 2000. Retrieved from http://onlinelibrary.wiley.com/journal/10.1111/(ISSN)1083-6101

20. Ellison N. B., Steinfield C., Lampe C.(2006). "The Benefits of Facebook'. Friends:" Social Capital and College Students' Use of Online Social Network Sites". Journal of Computer Mediated Communication.12 (3) no. (1). Retrieved from http://www.danah.org/SNSResearch.html

21. Feldman, Tony (1997). Introduction to Digital Media. New York: Routledge.

22. Feldon, Tony (2005). An Introduction to Digital Media. Chap. 1, p.13.New York: Routledge.

23. Forbes.com (2015). 'Terrorist Use Of U.S. Social Media Is A National Security Threat'. http://www.forbes.com/sites/realspin/2015/01/30/terrorist-use-of-u-s-social-media-is-anational-security-hreat/\#2a26ae6912d0

24. Funch, Ch. \& Sandoval, M. (2014). Critique, Social Media and the Information Society (ed). p.55. NewYork: Routledge.

25. Greenhow, Ch. (2011).Online Social Networking and Learning: What Are the Interesting Research Questions? International Journal of Cyber Behavior, Psychology and Learning, 1(1), 36-50, January -March (2011). 
26. Gregory, Jenny (2015). Connecting with the past through social media: the 'Beautiful buildings and cool places Perth has lost' Facebook group. International Journal of Heritage Studies, 21:1, 22-45, Retrieved on 4 july, 2015 http://dx.doi.org/10.1080/13527258.2014.884015.

27. Hampton, K. N., Lee, C.j., \& Her, E. J. (2011). How new media affords network diversity: Direct and mediated access to social capital through participation in local social settings. New media \& society, http://nms.sagepub.com/content/early/2011/02/09/14614448103903 42.

28. Hargittai, E. (2007). Whose Space? Differences among Users and Non-Users of Social Network Sites. $\quad J C M C, \quad 13$ (1). Special Issue of JCMC on Social Network Sites, Eds.: danah boyd and Nicole $\quad$ Ellison. Retrieved from http://www.danah.org/SNSResearch.html

29. Hille, Sanne \& Bakker, Piet (2014). Engaging the Social News User. Journalism Practice, 8 (5), 563-572. Routledge.

30. Hoechsman, M \& Poyntz, S. (2012). Media Literacies: A Critical Introduction. Blackwell Publishing Ltd.

31. http://en.wikipedia.org/wiki/Google\%2B\#cite_noteNew_York_Times_article_on_Google.2B-8

32. http://latimesblogs.latimes.com/technology/2011/12/google-may-reach-400-million users-by-end-of-2012.html

33. http://www.alexa.com/siteinfo/facebook.com Retrieved on feb 5, 2012

34. http://www.alexa.com/siteinfo/twitter.com Retrieved feb 5, 2012

35. http://www.statista.com/statistics/264810/number-of-monthly-active-facebook-users-worldwide

36. https://www.msu.edu/ nellison/EllisonLampeSteinfield2009.pdf

37. Hwa Ang, P. \& Steinfield, Ch. (2015). The International encyclopedia of Digital Communication and Society (1st ed), vol. 1, P.P-305-306. Retrieved on 14 january, 2016 from

38. Joinson, Adam N. (2008). Looking at, looking up or keeping up with people? Motives and use of Facebook. Test. SIGCHI 2008,p.p-1027-1036.<www.danah.org>

39. Kapidzic, Sanja and Martins, Nicole (2015). Mirrioring the Media: the Relationship Between Media Consumption, Media Internalization and Profile Picture Characteristics on facebook. Journal of Broadcasting and Electronic Media. 59(2).pp. 278297. Routledge.

40. Mukherjee, Kalyan., \& Bordoloi, Nabasmita. (2014). Corporate social responsibility of central public sector enterprises with special reference to North-Eastern electric power corporation limited and national hydroelectric power corporation limited. Int. J. Res. Busi. Manag, 2(3), 107-118.

41. Kim, Junghyun \& Jong-Eun Roselyn Lee (2011). The Facebook Paths to Happiness: Effects of the Number of Facebook Friends and Self-Presentation on Subjective Well being. Cyberpsychology, Behavior, and Social Networking. Vol. 14(6): 359364. doi:10.1089/cyber.2010.0374.

42. Kothari, C.R. (2004). Research Methodology: Methods and Techniques (2 ${ }^{\text {nd }}$ ed. ). New Delhi: New Age International (P) Ltd.

43. Kramer, Adam D. I, Jamie E. Guillory \& Jeffrey T. Hancock (2014). Experimental Evidences of Massive- Scale Emotional Contagion through Social Networks. Proceedings of National Acadamy of Sciences of United States of America. 111, (24). June 17, 2014.

44. Krippendorff, K. (1980). Content analysis: An introduction to its methodology. Beverly Hills: Sage Publications. 
45. Krishnamurthy, S. (2004). The Ethics of conducting e-mail survey. In E.A Buchanan (Ed.), Reading in Virtual research ethics: Issues and controversies (pp 114.129). Hershey, PA:Information Science.

46. Kuss, D. J., \& Griffiths, M. D. (2011). Online Social Networking and Addiction-A Review of the Psychological Literature. International Journal of Environmental Research and Public Health, 8(9), 3528-3552.

47. Lake, Ronald L.D. and Robert Huckfeldt. (1998) "Social Capital, Social Networks and Political Participation". Political Psychology. 19, (3), Special issue Psychological Approaches to Social Capital (Sep. 1998) pp. 567- 584. Retrieved on $17 f e b$. 2014.www.jstor.org/stable/3792178

48. Leppanen, S., Pitkanen-Huhta, A., Piirainen-Marsh, A., Nikula, T. and Peuronen, S. (2009), Young People's Translocal New Media Uses: A Multiperspective Analysis Of Language Choice And Heteroglossia. Journal of Computer-Mediated Communication, 14: 1080 - 1107.

49. Lim, Chaeyoon. (2008). Social networks and political participation: How do networks matter? Social Forces, 87(2), 961-982. Journalism and Mass Communication Quarterly, 76(4), 646 -658.

50. Lin, Nan (2010). Social Capital: A theory of the Social structure and action. Chap.4, p.p. 41-54. Cambridge: Cambridge University Press.

51. Livingstone S. (2008). "Taking Risky Opportunities in Youthful Content Creation: Teenagers use of Social Network Sites for intimacy, Privacy and Self expression”. New Media and Cyberculturals Anthology, edited by Pramod K. Nayar, WileyBlackwell publication.

52. Marwell, G., Oliver, E.P. \& Prahl, R. (1988). Social Network and Collective Action: A Theory of Critical Mass. American Journal of Sociology. 94 (3), 502-534. Retrieved January 18,2015 from http://www.jstor.org/stable/2780252.

53. Mathur, K. Parshant (2011). Social Media and Networking: Concepts, Trends and Dimensions. Chap.2, P.39. New Delhi: Kanishka Publishers.

54. McQuail, Denis . 'McQuail's Mass Communication Theory'. 5th edition(1983) SAGE Publication.

55. Newton, K. (1997). Social capital and democracy. American behavioral scientist, 40(5), 575-586.

56. Newton, K. (1999). Social capital and Democracy in Modern Europe. In Deth Van W. J., Maraffi M., Newton, K. \& Whiteley, F.P. (Eds), Social Capital in European Democracy (chap. 1, pp.3-4). New york: Routledge.

57. Ordini, S. \& Saunder, J. (2007). Social Media Use for News and Individual's 'Social Capital' Civic engagement and Political Participation. Journal of Computer Mediated Communication, 17(3) p.p 319-336. Retrieved from http://www.danah.org/SNSResearch.html

58. Papacharissi \& Mendelso (2011). Towards a New(er) Sociability: uses, gratification and social capital on Facebook. pub. In 'Media Perspactives for the 21st Century' by Stylianos Papathonasspoulos. Landon: Sage.

59. Putnam, D. Robert (2000). Bowling Alone: The Collapes and Revival of American Community. $\quad$ New York: Simon and Schuster Paperback. Citation from <books.google.co.in>

60. Putnam, D. Robert and Kristin A. Goss (2002). Democracies in Flux: The Evolution of Social

Capital in Contemporary Society. Chap-1, P.p 4-19, New York: Oxford University Press.

61. Rajasekher, T. and k. Vijayasree (2012). "Effect of emotions and sociability on human decisions". Indian Journal of Positive Psychology, Vol-3, no. 4.

62. Razdan, A. (2008). New Media: Techniques and Trends. New Delhi. Vistasta publishing Pvt. Ltd. 
63. Ritzer, George (2005). Encyclopedia of Social Theory, vol- 11. P.715. USA: SAGE Publication.

64. Ruggiero, T.E. (2000), "Uses and gratifications theory in the 21st century. Mass Communication \& Society, Vol. 3 No. 1, pp. 3-37.

65. Satista (2016). 'Number of monthly active Facebook users worldwide as of 1st quarter 2016' (in millions). Retrieved on 23 may, 2016 from http://www.statista.com/statistics/264810/number-of-monthly-active-facebook-users-worldwide.

66. Serageldin, Ismail \& Christiaan Grootaert (2002). Defining Social Capital: integrating view. In Dasgupta, P. \& Serageldin (2002). Social Capital: A Multifaceted perspective. Chap. 4, p.49. Washinton DC: The World Bank.

67. Sibona C., Walczak S., (2011). Unfriending on Facebook: Friend Request and Online/ offline Behavior Analysis. Proceedings of the 44th Hawaii International Conference on System science.

68. Stangor, C. (2004). Social Group in Action and Interaction. Chap. 5, p. 112. New York: Psychology Press.

69. Steinfield, Charles, Ellison, Nicole, and Lampe, Cliff. (2008). Social capital, self-esteem, and use of online social network sites: A longitudinal analysis. Journal of Applied Developmental Psychology, vol-29, no. (6).

70. Thapa, D., K. Sein, M. and Sabo, O. (2012).Building Collective Capabilities through ICT in a Mountain region of Nepal: Where social capital leads to collective action. Information Technology for Development. 8(1), p.p 5-12. Retrieved January 18, 2015 from http://tandfonline.com/loi/titd20.

71. The Economics Times (2015). 'Section- 66A of IT Act: Renu Srinivasan, Shaheen Dhada's family happy nobody else will suffer'. The Economics Times, ET Bureau, 25th March, 2015.(onlineversion). Retrieved on 26th March, 2105 fromhttp://articles.economictimes.indiatimes.com/2015-03-25/news/60475357_1_renu-srinivasan-facebook-account-palgharpolice-station

72. The Hindu (2013). The child was sold for 8 lakhs to a Delhi businessman by Facebook. The Hindu, 24th April, 2013. (epaper). Reterived on 24th April, 2013from:-<http.www.thehindu.com/todays-paper/tp-national/baby-sold-in-three-times-in-10 days/article4652146.ece>

73. The Hindu (feb 1. 2011). http://www.thehindu.com/opinion/interview/article1143693.ece. Retrieved on feb 5, 2012

74. The Hindu (july 8, 2011). 'Social media altering communication process'http://www.thehindu.com/todays-paper/tp-national/tpkerala/article2210224.ece

75. The Times of India (2013). 'Facebook profile may expose mental illness, says study'. The Times of India, 28th January, 2013(online version). Retrieved from <http:www.timesofindia.indiatimes.com/home/sciencel Facebook-profile-may-exposemental illness-says study/articlehow18215966.cms >

76. The Times of India (2013). Dumped by Facebook boyfriend, 14-year-old schoolgirl hangs self. Times of India, 7 th November, 2013 (online-version). Retrieved from -<http://timesofindia.indiatimes.com/citybangalore/dumped-by-facebookboyfriend-14-years-old-schoolgirl-hang-herself/articlehow25338418.cms>

77. The Times of India (2013). Social media is a security threat: Expert. http://timesofindia.indiatimes.com/city/bengaluru/Socialmedia-is-a-security-threat-Expert/articleshow/26983917.cms

78. Urista M., Dong \& Day (2011) “Explaining Young Adults Use of Myspace and Facebook, Through Uses and Gratification”. Proceedings in Hawai International Conference. http://www.danah.org/SNSResearch.html

79. Vaccari, C., Valeriani,A., Barbera, P., Bonneau, R., Jost, J. T., Nagler, J., \& Tucker, J. A. (2015). Political Expression and Action on Social Media: Exploring the Relationship Between Lower-and Higher-Threshold Political Activities Among Twitter Users in Italy. Journal of Computer-Mediated Communication, 20(5), 221-239. 
80. Valenzuela, S., Park, N. \& Kee, Kerk F. (2009). Is there social capital in a social network site?: Facebook use and college students' life satisfaction, trust, and participation. Journal of Computer-Mediated Communication, 14 (4), 875 - 901.

81. Valenzuela, S., Park, N., and Kee, Kerk F. (2009). "Is there social capital in a social network site?: Facebook use and college students' life satisfaction, trust, and participation”. Journal of Computer-Mediated Communication, 14 (4), p.p 875 - 901.

82. Vitak, J., Ellison, N., and Steinfield, C. (2011). Re-examining the relationship between Facebook use and bonding social capital: A focus on social provisions. 44th Annual Hawaii International Conference on System Sciences.Kauai, HI January. (www.danah.org)

83. Warren, M.A., Sulainman, A. \& Jaafar, I. N. (2015). Understanding Civic Engagement Behaviour on Facebook from a social Capital theory Perspective. Behaviour \& Infromation Technology, 34 (2), $\quad$ 163-175, Retrieved on 4 july, 2015 from http:/dx.doi.org/10.1080/0144929x.2014.934290.

84. Wellman, B., Haase, A. Q., Witte, J., \& Hampton, K. (2001). Does the Internet increase, decrease, or supplement social capital? Social networks, participation, and community commitment. American behavioral scientist, 45(3), 436-455.

85. Whiteley, F. Paul (1999). 'The origin of Social Capital' . In Deth, Van W. Jan, Maraffi, M., Newton, K. \& Whiteley, F. Paul. Social Capital and European Democracy. Chap. 2, 25-44. Landon, NewYork : Routledge.

86. William A. Darity Jr. (2008). International Encyclopedia of the Social Sciences, 2th Edition', P. 564. GALE CENGAGE learning.

87. Arora, Shruti., \& Sharma, Anukrati. (2013). Social media as a successful tool of brand awareness. International Journal of Business and General Management (IJBGM), 2(3), 1-14.

88. Woolcook, M. (2001). The Place of social capital in understanding social and economic outcomes. Canadian Journal of Policy Research, 2(1), 11.17.

89. Yang T. A., Kim, D. J., \& Dhalwani, V. (2007). Social Networking as a New Trend in E-Marketing. Research and Practical Issues of Enterprise Information Systems II,2(1), 847-856. Retrieved from http://link.springer.com/chapter/10.1007\%2F978-0$\underline{387-763125 \_7}$

90. Zuniga Homero G. D. (2012) “Social Media Use for News and Individual's 'Social Capital' Civic engagement and Political Participation”. Journal of Computer Mediated Communication, 17, (3), p.p 319-336. 